\title{
Teacher Codeswitching in the EFL Classroom
}

\section{Yuri Hosoda}

Temple University Japan

Language teachers' use of their students' native language during second/foreign instruction is often viewed negatively, even by the teachers themselves. However, teachers' occasional codeswitching between the target language and their students' L1 may have some positive effects. The present study analyzes the codeswitching of a Japanese teacher in one EFL classroom. The data shows that the teacher's codeswitching into the students' L1 not only performed a number of social functions, but also played an important interactional role.

語学教師による学生の第一言語の使用は教師自身によって否定的に捉えられている。し かしながら教師による学生の第一言語と目標言語とのコード切り替えは、時として肯定的 な効果もあると考えられる。本研究は、一人の日本人教師の英語授業内におけるコード切 り替えを検討した。分析の結果、教師の日本語と英語のコード切り替えは教室内でいくつ かの社会的役割を持つばかりでなく、談話における重要な役割を持っていることがわかっ た。

I $\mathrm{t}$ is generally agreed that Japanese is the main language used for English instruction in the majority of English as a Foreign Language (EFL) classes taught by Japanese teachers in Japan. Kaneko (1991) investigated 12 Japanese junior and senior high school EFL classes and found that the teachers spent approximately $70 \%$ of the time instructing the students in Japanese. Similarly, LoCastro (1996) points out "the strong preference for the use of Japanese" (p. 49) in a great majority of Japanese EFL classes. However, as Polio and Duff (1994) have argued, it may not be reasonable to expect nonnative teachers to use the target language (TL) exclusively, since the teachers themselves have probably had limited exposure to the TL and its culture.

In general, use of the first language (L1) in EFL or ESL (English as a Second Language) classrooms has been controversial. Some researchers have found benefits in using the students' L1, especially in facilitating the development of useful learning strategies (e.g., Atkinson, 1987; Auerbach, 1993). However, the TL-only notion is still so powerful that EFL/ESL teachers who admit that they use the students' L1 in their 
classes are usually apologetic (Adendorff, 1996; Auerbach, 1993; Canagarajah, 1995).

The aim of the present paper is to describe some positive effects of one teacher's English-Japanese codeswitching (CS) behavior in an EFL classroom in Japan.

\section{Research on Codeswitching}

Codeswitching is defined as the "alternations of linguistic varieties within the same conversation" (Myers-Scotton, 1993c, p. 1) and is recognized as a "common characteristic of bilingual speech" (Grosjean, 1982, p. 146). Dabène (1990) divides CS into two types: CS by incompetence and intentional CS. Earlier works on CS focused on the CS by incompetence model and CS was thus regarded as a remedial strategy used by people who were not fluent in the L2. ${ }^{1}$ However in a study of CS between dialects in a Norwegian village, Blom and Gumperz (1972) showed that CS is indeed the normal behavior of bi-/multilinguals since it fulfills various sociolinguistic functions. Although the study dealt with CS between dialects, not languages, it stimulated considerable subsequent research on CS between languages (Myers-Scotton, 1993c). Thereafter, research on CS often focused on what Dabène (1990) termed intentional CS (e.g., Dabène, 1990; Dabène \& Billiez, 1986; Eastman, 1992), and now such linguistic variation is considered "a strategy for accomplishing something" (Myers-Scotton, 1993c, p. 94). ${ }^{2}$

There are two main types of research on CS: linguistic research and sociolinguistic research. The former analyzes the syntactic nature of a switch, examining the type of grammar a bilingual speaker uses in both languages and investigating which grammatical items tend to be switched. Research investigating the grammatical features of CS between two typologically different languages (e.g., Kato, 1994; Nishimura, 1989) as well as two typologically similar languages (e.g., Poplack, 1980) has found that CS is syntactically rule-governed regardless of the typological difference between the two languages. Regarding this point, Myers-Scotton (1993b) claims that "typological specifics of the language pair may determine the options chosen, but the options themselves are not language-specific" (p. 492). Myers-Scotton's claim is reflected in her Matrix Language-Frame model (Myers-Scotton, 1993a; 1993b), which views the basic constraints of CS in any two languages as being under the control of the same abstract production process. In terms of grammatical items that are subject to CS, switches of nouns or other single items have generally been found to be the most frequent (see Fotos, 1995; Kato, 1994; Poplack, 1988). ${ }^{3}$ 
The second type of CS research, sociolinguistic research, attempts to investigate the sociolinguistic functions of a switch. Two kinds of CS have been proposed: situational and conversational, or metaphorical (Blom \& Gumperz, 1972; Gumperz, 1982). In situational codeswitching, people switch codes in association with particular settings or activities. This type of CS can be linked to the concept of diglossia in society (Gardner-Chloros, 1991). In conversational or metaphorical CS, people employ CS within a single speech exchange to convey "metaphorical" meaning. This type of CS is closely associated with the individual's discourse style and his/her language choices. While many researchers find the distinction between the two types of CS useful, some researchers have found problems with the distinction, claiming that the use of the terms is ambiguous or inconsistent (e.g., Auer, 1984; Myers-Scotton, 1993c). ${ }^{4}$

Studies of the sociolinguistic aspects of CS have examined the motivations underlying CS. For example, CS has been used to "express shared ethnic identity" (Nishimura, 1995, p. 157), to show shared experience and solidarity (Duppenthaler \& Yoshizawa, 1997), to encode power and solidarity (Goyvaerts, 1992), to accommodate to the linguistic environment (Gardner-Chloros, 1991), and to "express authority along with anger or annoyance" (Myers-Scotton, 1993c, p. 133).

Most research of CS in ESL/EFL classrooms has investigated how CS performs various sociolinguistic functions, although L2 learners' CS between the L1 and the TL has often been regarded as due to low proficiency in the TL. However, recent research findings have shown that students' CS may be intentional and may fulfill various social functions. Fotos (1995) looked at learners' CS in EFL classrooms in Japan. Her analysis of CS indicated that her subjects switched from English into Japanese to: 1) indicate topics; 2) emphasize important utterances; 3) clarify; 4) frame discourse; 5) separate feelings from facts; and 6) signal repair. Her subjects' use of these functions suggests that they were successful both in making their speech salient to their listeners and enriching their speech. Ogane (1997) also looked at EFL learners' CS in an English classroom in Japan. She found that the learners used CS both to involve their interlocutors in communication and to express "their dual identities of L1 speaker and L2 learner" (p. 119).

Studies which examine teachers' CS have also explored the sociolinguistic functions of codeswitching. Canagarajah (1995) studied teachers' CS in L2 classrooms in Jaffna and found that CS served useful functions for classroom management and content transmission. Summarizing the different functions that CS served in the classrooms, Canagarajah concludes that English is generally used as the code symbolizing for- 
mality or detachment, while Tamil is used as the code which expressed informality and familiarity. Merritt, Cleghorn, Abagi and Bunyi (1992) examined teachers' CS among English, Swahili, and mother tongues ${ }^{5}$ in three primary schools in Kenya. They found that CS between languages is often used in order to focus or regain students' attention or to clarify lesson materials. Much like Canagarajah (1995), they also found that the Kenyan teachers used their mother tongue or Swahili for more affectively positive matters and English for more formal matters. Thus, these two studies have linked teachers' CS in classrooms with affective factors. However, there have been few studies investigating Japanese teachers' CS in EFL classrooms.

\section{Research Questions}

The present study describes a Japanese teacher's CS behavior in an EFL classroom and addresses the following three questions:

1. What are the functions of teacher L1 use or CS in the Japanese EFL classroom?

2. In what discourse context does teacher CS tend to occur?

3. What are some effects of teacher CS in the classroom?

\section{Method}

The data analyzed for this study are based on 23 minutes taken from a 60-minute video-recorded EFL class and a subsequent audio-recorded session in which the teacher and the students viewed and discussed the 23-minute segment. This retrospective session was conducted one week after the video-recorded class session.

\section{Subjects}

There were only two male Japanese students registered for the EFL class and these students agreed to be video- and audio-recorded. They were enrolled in a required elementary level first-year Business English class taught by a Japanese teacher (the writer of this paper) at a business college in Tokyo. Shin and Taro (not their real names) were 19 years old at the time of recording. The class met once a week for 60 minutes and the aim of the course was to equip students with the basic English conversational skills needed for business. Although both students had studied English in junior and senior high school for a total of six years, this was their first experience studying conversational English. At the time of the recording they had been studying English at the business college for five months. 
The students' English proficiency and motivation for studying English was low. Shin had passed the third (next to the lowest) level of the STEP (the Society of Testing English Proficiency) test ${ }^{6}$ when he was in high school but he refused to study for subsequent proficiency tests. Taro had passed the fourth level of the STEP test when he was in junior high school but had not taken any proficiency tests since. Although the teacher usually spoke only English in her other classes, in this type of class, with students at such a low proficiency level, she sometimes used the students' L1, Japanese, as well.

\section{Procedures}

A 60-minute lesson was video- and audio-recorded at the business college and a 23-minute segment was transcribed and analyzed. The video camera was placed in front of the students throughout the lesson and the audiocassette recorder was placed on a table between the two students. The 23-minute segment occurred approximately two minutes after the class started and can be divided into three parts. In the first part the teacher and the students casually talked about how they spent their weekend. In the second part the students worked on a "strip story" activity" based on a dialogue. Although they had studied the dialogue previously, the activity was quite difficult for them and it took over 10 minutes to finish. In the third part the students tried to perform a pair activity, but had considerable difficulty understanding the procedure. The remainder of the lesson was not transcribed because the students worked on the pair activity by themselves and there was little teacher-student interaction.

One week after the recording the students were asked to attend a playback session of the 23-minute segment and this retrospective session was also audio-recorded. The session was conducted outside the class time. Following Tannen's (1984) suggestions that it is important for a researcher to give control of the recorder to the subjects-especially when the researcher is one of the subjects-to make comments on their own ideas, the teacher/researcher attended the session, but refrained from comment. However, when the students did not discuss a part of the tape that the researcher was interested in, she played the part again and elicited their comments through use of general questions in Japanese such as "What is going on in this segment?" or "How did you feel then?"

\section{Transcription and Analysis of the Data}

The 23-minute segment was first transcribed using a simplified version of the Jefferson transcription system (Atkinson \& Heritage, 1984). After identifying all occurrences of CS the researcher retranscribed each instance in detail, relying on both the audio-tape and video-tape. Cod- 
ing and interpreting was done with the help of several additional coders who were qualitative researchers. Although inter-rater reliability was not established, the coding of the examples was checked repeatedly through discussions, as suggested in the CS literature (e.g., Canagarajah, 1995; Fotos, 1995). In the transcript, the Japanese switches are given in italics, and idiomatic translations are provided under the Japanese utterances. Since an interactional sociolinguistic approach was used for analyzing the data, presentation of the transcribed portions in "close transcription" format is suggested to be necessary. The Jefferson system (see the transcription conventions in the Appendix) is the most widely used system in the field of discourse/conversation analysis and is designed to represent dynamics of turn taking such as overlaps, gaps, pauses, and audible breathing, and characteristics of speech delivery such as stress, enunciation, intonation, and pitch (see the discussion in Hutchby \& Wooffitt, 1998). In the past, researchers have argued that turn-taking (e.g., Sacks, Schegloff, \& Jefferson, 1974) and prosody (e.g., Gumperz, 1982) convey significant meanings, and the interpretations of the present data are largely based on those characteristics of discourse. Therefore, the notation of these features in the transcripts is necessary to support interpretation of the data.

Close transcription has been mentioned (Davis, 1992; 1995; Brown, in press) as an important criterion contributing to the credibility of discourse analysis such as in the present research. Here credibility refers to demonstrating that the researcher's reconstruction of meaning is a believable and accurate version of the discourse studied (Davis, 1992; 1995; Brown, in press). Research in discourse analysis must, therefore, achieve credibility by attaching transcripts of audio and video recordings giving the talk and actions that have occurred, thereby allow the readers to reanalyze and check the author's interpretations for themselves.

Full transcription also contributes to confirmability, the "full revelation or at least the availability of the data upon which all interpretations are based" (Brown, in press, p. 328). As mentioned, most of the interpretations in this research are based on both video- and audio-recorded interactions in the classroom, so it is necessary for the transcript portions presented to show as much detail as possible.

\section{Results and Discussion}

In the first $51 / 2$ minutes of the 23-minute segment Shin and Taro talk about what they did on the weekend and the teacher does not use any Japanese. It is after the 51/2-minute segment that the teacher begins to use 
some Japanese. At this point she introduces the first activity. As shown in Table 1, in the rest of the transcribed segment, the teacher uttered 140 Japanese words (approximately 18\% of the total number of words in this segment as measured by a word processor word count function).

Table 1: Frequency of Teacher's L1 and L2 Use

\begin{tabular}{llll}
\hline Language & English (TL) & Japanese (L1) & Total \\
Number of words & $618(81.53 \%)$ & $140(18.47 \%)$ & $758^{*}(100 \%)$
\end{tabular}

${ }^{*}$ In counting words, backchannels (e.g., un, mhm, uhuh), short responses (e.g. un, yes), and proper nouns (e.g., Taro, Shin, A, B) were omitted.

The functions of teacher CS will now be examined. Any use of Japanese by the teacher is considered to be CS because the base language in the teacher's utterances during the lesson is English, as shown in Table 1. The discourse environment in which the CS took place will then be examined, especially the students' reactions. Finally, the effect of CS on the discourse will be discussed.

\section{Types of Codeswitching}

Analysis of the data revealed that most of the teacher's CS occurred in four contexts: (1) Explaining prior L2 utterances; (2) Defining unknown words; (3) Giving instructions; and (4) Providing positive and negative feedback. The number of each type of switch and the percentage of the total accounted for by each type of switch are presented in Table 2.

Examples of each type of CS are given and discussed below.

Table 2: Frequency of Each Type of Teacher CS

\begin{tabular}{|c|c|c|c|c|c|c|c|}
\hline & \multirow[t]{2}{*}{ explanation } & \multirow{2}{*}{\multicolumn{2}{|c|}{ definition }} & \multirow[t]{2}{*}{$\begin{array}{c}\text { Type of CS } \\
\text { instruction }\end{array}$} & \multicolumn{2}{|c|}{ feedback } & \multirow[t]{2}{*}{ Total } \\
\hline & & & & & negative & positive & \\
\hline \# times & $10(33.33 \%)$ & 7 & $(23.33 \%)$ & $5(16.67 \%)$ & $6(20.00 \%)$ & $2(6.67 \%)$ & $30^{*} \quad(100 \%)$ \\
\hline \# words & $63(45.00 \%)$ & 23 & $(16.43 \%)$ & $35 \quad(25.00 \%)$ & $14(10.00 \%)$ & $5(3.57 \%)$ & $140 * *(100 \%)$ \\
\hline
\end{tabular}

* Total number of times does not include the teacher's short response uns 'yes' to the students' questions. If those uns are included, the total frequency is 37.

**Total number of words does not include backchannel uns or short response uns. 


\section{Explanation of prior L2 utterances}

Explanation of prior L2 utterances was the most frequently occurring type of CS, with 10 occurrences (33.33\%) in the data. The teacher frequently provided an L1 "explanation" of what she had previously said in the TL by reformulating or repeating phrases or sentences. Fotos (1995) refers to this function of CS as "switching for emphasis." She found that both EFL students and bilingual children used CS to repeat important utterances. This kind of CS is also found frequently in research on ESL/EFL teachers' CS in the classroom (e.g., Canagarajah, 1995; Merritt et al., 1992; Polio \& Duff, 1994). Explanation in the L1 makes the content of teachers' talk easier for learners to understand. Furthermore, Canagarajah (1995) argues that teachers' reformulation or repetition in the L1 provides learners with "an opportunity to check their understanding of the previous statement" (p. 187). Although CS in this category may function as "emphasis" as well, as Canagarajah (1995) comments, in teacher-student interactions a major reasons that a teacher uses the $\mathrm{L} 1$ to repeat or reformulate what she has previously said in the TL is that the teacher feels that students' competence is too limited for them to understand lengthy statements in the TL and they need an L1 explanation. Therefore, I selected Canagarajah's term "explanation" over other similar ones in the literature. Instances from the present study are shown in Examples 1 and 2 (see Appendix for transcription conventions).

\section{Example 1}

147. Shin: A ga first.

'A is the first.'

148. Teacher: hh could you read A one more time? (.) >mouikkai A yonde mite< 'Would you read A once more?'

149. Shin: yomun desuka 'Do I read?'

150. Teacher: un

'Yeah.'

In the example above, the teacher repeats her English utterance in Japanese.

\section{Example 2}

((The teacher is talking while distributing slips of paper for the first activity.))

122. Teacher: You don't have to open your textbook yet. Don't 
open. I just want you to have these (2.0). Don't show it to Shin. Don't show it to Shin.

123. Shin: e nandesuka

'Huh? What?'

((The teacher finishes distributing slips of paper and goes back to her seat. The students remain silent.))

124. Teacher: You just read (.) and <find out (.) which comes first second third and fourth (.) find out the order.> (.) dorega saishoni kite douiu junjoka. (.)

misenai otagaini misenaide yomimasu (.) sorede kokoni kaitearukara $A$

ga saki toka $B$ ga saki toka $C$ ga saki toka $D$ ga saki toka ${ }^{\circ}$ futaride ${ }^{\circ}$

'Which one comes first and in what order? Don't show, don't show them to the other person. And as (the letters) are written here, you two work together and (figure out) which one comes first, A or B or C or D.'

Here the utterances in Japanese in line 124 reformulate the previous English statements in lines 122 and 124.

\section{Definition of unknown words}

Studies of CS in ESL/EFL classrooms often mention that teachers provide definitions of words in the students' L1 (e.g., Canagarajah, 1995; Polio \& Duff, 1994). This type of CS always occurred after the students asked for the meaning of words that had appeared in the texts, as shown in Example 3 below.

Example 3

((Shin is reading a slip of paper in the first activity.))

229. Shin: Maybe you (.) should be a se, securitary tte nandesuka

'What does "securitary" mean?'

230. Teacher: Secretary (.) bisho.

'Secretary.'

231. Taro: [((yawning))]

232. Shin: bisho

'Secretary.'

In Example 3, Shin asks the meaning of "secretary" and the teacher gives the Japanese counterpart, bisho. 


\section{Giving instructions}

CS for giving instructions is different from the previous types of CS (explanation of prior L2 utterances or definitions of unknown words) since what the teacher says in the $\mathrm{L} 1$ is neither a repetition of a previous utterance in the TL nor an answer to a student's request for the meaning of a word, but is totally new information. Merritt et al. (1992) claim that this type of CS can be used as a communication strategy which serves as a tool to focus or redirect students' attention. In the example below, the teacher accepts Shin's answer and tries to finish up the activity by having the students read the dialogue once more. When she tells students to read the dialogue again, she switches into Japanese.

\section{Example 4}

248. Shin:

ttekotowa B D [ A C ]?

249. Taro: [((clearing throat) $)]$

250. Teacher:

(?) [a:::nd ] jaa sono junban de saigo tadashii junbande mouikkai yondemimashou (.) bai

'Then, in that order, finally, in the correct order, let's read them again, go.'

251. Shin:

$\left[{ }^{\circ} \mathrm{B} \mathrm{D} \mathrm{A} \mathrm{C} \mathrm{C}^{\circ}\right]$

\section{Positive and negative feedback}

The teacher often switched into Japanese to inform the students that they were correct or to criticize them or say that they were wrong. According to Merritt et al. (1992), effective bilingual teachers often develop this type of ability, called "modality splitting" and referring to the differentiation of codes or channels according to differing communicative needs. Students gradually learn the significance of the use of specific codes for specific functions, so teachers can use modality splitting CS to orient students to various classroom requirements. In a number of foreign language classrooms it has been observed that teachers codeswitch along modality lines: one language (usually the TL) for instruction and the other (usually the L1) to signal affective emotions and asides (e.g., Adendorff, 1996; Canagarajah, 1995; Merritt et al., 1992). Similarly Gumperz (1982) distinguishes a "we code" (usually a minority language) and a "they code" (usually the majority language) and argues that the "we code" signifies more informality and intimacy than the "they code." In EFL classrooms in which use of English is the norm, Japanese seems to be the "we code" implying informality and friendliness.

In the present data the teacher primarily used English for instruction within the class. However, when she chatted with the students outside 
of the English class she always used Japanese. For example in the playback session in which the teacher and the students talked casually about the lesson, the teacher used only Japanese. Moreover one of Shin's comments in the playback session indicates that Japanese was the code the students wanted the teacher to use. He said, (translation) "In your class, you don't give enough explanation in Japanese. I always want you to speak more in Japanese." Thus, the teacher seems to have used Japanese for affective purposes rather than instructional purposes, especially when she gave positive and negative feedback.

Use of CS to provide positive feedback is also found in Canagarajah's study (1995), when teachers used the L1 to express compliments to students. Canagarajah suggested that compliments in the TL are routine, whereas compliments given in the L1 have impact and are more effective in strengthening the force of the speech act.

Positive feedback: In this paper, positive feedback refers to praise or a compliment uttered by the teacher. In the data there were only two cases of positive feedback, both of which were uttered in Japanese. ${ }^{8}$ The two cases occurred when the students accomplished something that was difficult for them. One instance took place when the students finished the first activity, and the other occurred when the students finally understood how to perform the pair activity. As explained in the previous section, completing the first activity and understanding the procedure of the second activity were the most complicated tasks for the students in the transcribed segment. When the students accomplished those tasks, the teacher praised them in Japanese, the code the students preferred the teacher to use, thus strengthening the force of the positive evaluation. In Example 5, the teacher provided positive feedback, un soudesu (Yes, that's right), with a high falling tone when Shin understood how to perform the second activity.

Example 5

303. Shin: de yousuruni kono can she [typel toka can she use a compu[ter] tokatte iufuuni kitte ikundesuka= 'And, in short, we are supposed to ask "can she type" or "can she use a computer" and so on?'

304. Teacher: [ un ]

[un]

305. Teacher: =un soudesu

'Yes, that's right.'

Negative feedback: Negative feedback in this paper refers to error correction or criticism given to the students. The teacher's negative 
feedback was always preceded by a student's language error or failure of some type. In providing negative feedback, the teacher sometimes used Japanese and the switches were almost always accompanied by Japanese final particles (e.g., desho, ne). Studies of final particles in Japanese often claim that these function as markers for showing an attitude of cooperation (e.g., Itani, 1996; Maynard, 1993). Regarding the mitigating or soothing effect of the L1, according to Canagarajah (1995), bilingual teachers often utter tags, discourse markers, particles, and backchannel cues in the L1 in order to reduce their perceived power over their students. In the following example, the teacher provides negative feedback in Japanese when she blames the students for their failure to remember what they have studied before, but softens the feedback with the final particles ne and desho.

\section{Example 6}

((The teacher and the students are discussing the first activity after its completion.))

267. Teacher: We did it before (.) summer vacation. (5.0)

268. Teacher: ${ }^{\circ}$ ne mitakoto arudesho?

See? You've seen it before, haven't you?'

269. Taro: [((nods strongly))]

270. Shin: [e] yarimashita koko.

'Really? Did we study this page?'

In line 267 , the teacher informs students that they have done the activity before. However, there is a long pause following line 267. This pause, as well as the difficulty the students had in completing the activity, suggests that the students did not remember performing the activity previously. Therefore the teacher's comment in line 268 is criticizing the students by indicating that they should have remembered the dialogue. However, by using Japanese, especially the final particles ne and desbo, the criticism is mitigated. As indicated in Examples 5 and 6, the teacher's L1 utterances strengthened the force of the act when she gave positive feedback and mitigated the force of the act when she provided negative feedback.

Thus in the present study the teacher used switches into the L1 to define unknown words, to explain prior L2 utterances, to give instruction, and to provide positive and negative feedback.

\section{Codeswitching "Triggers"}

In the previous section, several social functions of CS in teacher talk were explored, and as in most previous research, the analysis examined the utterances of the CS sender (i.e., the teacher). However, to understand 
the local environment in which the CS took place, it is necessary to examine the discourse environment of all participants in the speech act, especially the listeners' reactions. According to Bilmes (1997) listeners are active participants in interactions and send various signals in the form of facial expressions, postural variations, eye movements, and short vocalizations. Bilmes suggests that one can not understand what is going on in a social scene by examining the behavior of only one participant in the interaction.' Therefore, in this section, the focus is on students' verbal and nonverbal behavior in the discourse environment in which the CS occurred.

Interestingly, a closer look at the discourse environment revealed that regardless of the function the teacher's CS performed, it was always in response to the students' behavior, either "positive achievement" or "negative responsiveness." "Positive achievement" refers to the students' successful completion of a difficult task. In such cases, as presented in the previous section, the teacher provided "positive feedback" in Japanese. The teacher responded to the students' "positive achievement" by switching into Japanese, intensifying the force of the positive evaluation. In this case, CS functioned as an affect-creating device.

Students are considered to be showing "negative responsiveness" if they fail to give an appropriate response in a timely manner. ${ }^{10}$ When the students showed "negative responsiveness," the teacher occasionally responded by switching into the L1 for explanation, instruction, definition, or "negative feedback." As mentioned, CS for negative feedback has an affective function. Therefore, in the case of negative feedback, the teacher's CS represents not only a response to the students' negative responsiveness but a display of affect as well. The students' negative responsiveness may be a result of their lack of comprehension due to a lack of proficiency in the TL. However, some of the comments by Shin and Taro during the playback session indicate that their lack of comprehension may also be due to boredom, uneasiness, sleepiness, or discomfort. In the playback session, both Shin and Taro admitted that they had felt uncomfortable during the lesson. Shin said, (translation) "I felt dull and sleepy during the lesson," and Taro said, (translation) "I felt reluctant to study." Moreover, Taro expressed the high anxiety he had felt during the lesson. He said (translation), "I felt very nervous about being called on throughout the lesson." The students' negative responsiveness was indicated verbally and nonverbally, as will be explained below.

\section{Verbal indicators of "negative responsiveness"}

Verbal indicators of negative responsiveness shown in the data included verbal expressions of incomprehension or incorrect interpretation of the teacher's TL input by the students, as in the following examples. 


\section{Example 7}

190. Teacher: Shin (from the first one) would you read the two.

191. Shin: miselte]

'\{Should I\} show \{you\}?'

192. Teacher: $\quad>$ Iryolubou ryoubou yonde< un

'Both, read both, uh-huh.'

193. Shin: ((reading)) D ga "I'm not sure I can type pretty well (.) Maybe you should be a secretary."

In the example above, the teacher tells Shin to read two slips of paper in line 190, but Shin interprets her utterance as a request to show the slips to the teacher. As soon as Shin starts to say misete 'SShould I\} show \{you\}?' in line 191, the teacher notices Shin's lack of comprehension of her prior TL utterance and therefore switches into the L1 for an explanation (line 192). The teacher's Japanese utterance is then followed by Shin's compliance as he begins to read (line 193). In the next segment, the student also expresses his incorrect interpretation verbally.

\section{Example 8}

((Taro has been told to read a slip of paper labeled "A" but starts reading "B."))
161. Taro: I'm starting to.
162. Teacher: sore $B$ desho?
'That's B, isn't it?'
163. Taro:
a bontoda.
'Oh, that's right.'
164. Shin:
'oi yare yare
'Oh, come on.'
165. Taro: ((starts reading "A")) "But also speak French. I'd like to use that. (.) Do you like to meet people?"

In line 161, Taro starts reading a slip labeled "B" instead of " $\mathrm{A}$ " by mistake. The teacher switches into Japanese to give Taro negative feedback, saying that he is reading the wrong strip (line 162). Taro acknowledges his mistake (line 163) and starts reading " $\mathrm{A}$ " (line 165). However, what is of interest in this segment is Shin's comment in 164. Shin utters oi yare yare (Oh, come on!), a comment that may indicate that Taro's mistake has had a negative effect on the flow of the lesson and the teacher's switched utterance has helped Taro to get back on the "right track" in the interaction.

Nonverbal indicators of "negative responsivenes"

Nonverbal indicators of negative responsiveness include silence, short nods, sighs, yawns, wry grins, giggles, throat clearing, head tilting, look- 
ing at the other student, asking the other student privately, or a combination of these features. Among these, silence and short nods are the features that occurred most frequently before the teacher's CS. Silence often indicates interactional problems. For example, in her research on an EFL classroom in Japan, Fujita (1997) found that a long silence following a teacher's question created an uncomfortable atmosphere in the classroom. Short nods may also indicate problems in interaction. Here, short nods refer to relatively brief unaccented nods without vocalization. Writing about Japanese conversation, Mitsuo (1997) notes that "occurrences of these nods without vocalization or minimal vocalizations without nods are associated with a listener whose attention is distracted" (p. 37).

Mitsuo's findings are supported by one of Taro's comments during the playback session. Watching himself make short nods, he said (translation),

I think I was not comprehending what the teacher was saying at this point. This is the kind of nod I make when I don't understand messages but pretend that I do in order not to disturb the flow of the lesson.

Taro further commented on a minimal vocalization, "yes" without a nod, as the kind of "yes" he usually utters without comprehension or attention. These features, silence and short nods, often occurred in combination with the other features listed above. The following are some examples.

\section{Example 9}

((The teacher is explaining how to do the first activity. In the transcript, ' $t$ ' indicates Taro's gesture, " $s$ " indicates Shin's gesture, " $n$ " indicates a short nod, and ' $\mathrm{N}$ ' indicates a strong nod. These nonverbal indicators are shown in a line above each sentence.))

120. Teacher: Since it's been long <since we worked on the text
$\mathrm{t}: \mathrm{n}$
$\mathrm{t}: \mathrm{n}$

book last time we are

((t: scratching head)) ((t \& s: look at each other $))$ going to review the unit (.) we worked on last time.> (1.5) so

121. Taro: ((giggles))

122. Teacher: you don't have to open your textbook yet don't $\mathrm{t}: \mathrm{n} \mathrm{n} \mathrm{n}$ open. (.) I just want you to have these ((Teacher hands out slips of paper to Taro.)). Don't show it to Shin. Don't show it to Shin. 
123. Shin: e nandesuka?

'Huh? What?'

(4.0) ((The teacher finishes distributing slips of paper and the students remain silent.))

124. Teacher: You just read (.) and < find out (.) which comes first t:n t:n t:n

second third and

$$
\mathrm{t}: \mathrm{n} \mathrm{n} \mathrm{t}: \mathrm{n} \text { t:n } \mathrm{n} \quad((\mathrm{t} \text { : grins wryly }))
$$

fourth (.) find out the order.> (.) dorega saishoni kite douiu junjoka. (.)

misenai otagaini misenaide yomimasu (.) sorede kokoni kaitearukara A ga sakitoka B ga sakitoka C ga sakitoka $D$ ga sakitoka ${ }^{\circ}$ futaride ${ }^{\circ}$

'Which one comes first and in what order. Don't show, don't show them to the other person. And as \{the letters\} are written here, you two work together and \{figure out\} which one comes first, A or $\mathrm{B}$ or $\mathrm{C}$ or $\mathrm{D}$.'

\section{s: $\mathrm{N}$ N N N N}

125. Shin: $\quad a::$ baa baa baa haa wakarimashita.

'Oh, hum, hum, hum, hum, I see.'

Commenting on this segment in the playback session, both students admitted that they felt extremely dull, sleepy, and uneasy. These feelings are reflected in their nonverbal behavior. During the teacher's turn in line 120 , the students make various nonverbal signs. Taro gives short nods, scratches his head, then both students look at each other. There is a relatively long silence ( 1.5 seconds). The turn is then followed by Taro's giggle in line 121. The teacher continues explaining in the TL in line 122. During the turn, the students remain quiet, and Taro gives some short nods. In line 123, Shin expresses his lack of comprehension verbally. In line 124 , the teacher keeps explaining in the TL very slowly; however, during the explanation, the students again send various nonverbal signs such as short nods, a wry grin, and silence. Finally in the middle of line 124, the teacher switches into a Japanese explanation. This is immediately followed by Shin's positive response to the teacher's utterance in line 125 . The next example also illustrates the students' nonverbal negative responsiveness. 
249. Taro:

[((clearing throat $))]$

((s: sigh))

250. Teacher: Uh-huh oh kay (?) [a:::::nd] jaa sono junbande saigo tadashii junbande mouikkai yonde mimashou (.) bai 'Then, in that order, finally, in the correct order, let's read them again.'

251. Shin: $\left[{ }^{\circ} \mathrm{B} \mathrm{D} \mathrm{A} \mathrm{C}{ }^{\circ}\right]$

252. Taro: ((reading)) I'm starting to look for a job. (.) What kind?

In the example above, Taro's throat clearing in line 249 and Shin's sigh during the teacher's turn in line 250 are followed by the teacher's switch into Japanese. After the switch, the students immediately follow the teacher's instructions (lines $251 \& 252$ ). In the next example Taro's yawn and both students' relatively long silence seems to trigger the teacher's CS.

\section{Example 11}

((The teacher and the students are talking about the first activity.))

265. Teacher: That's uh:: <page eighteen.>

266. Shin: (1.0) ((Taro yawns))

267. Teacher: We did it before (.) summer vacation. (5.0) ((Both Shin and Taro look down at Shin's textbook and remain silent.))

268. Teacher: ${ }^{\circ}$ ne mitakoto arudesho?

'See? You've seen it before, haven't you?'

269. Taro: [((nods strongly $))]$

270. Shin: [e] yarimashita koko

'Really? Did we study this page?'

271. Teacher: un yarimashita

'Yes, we did.'

In line 265, the teacher tells students to look at page 18 of the textbook. However, Taro yawns without following her instructions. In line 267, the teacher tells the students that they studied it before summer vacation. The students then look down at the textbook and remain silent for five seconds. While the students are still looking at the textbook, the teacher criticizes the students softly in Japanese, saying ne mitakoto arudesbo? "you've seen it before, haven't you?" in line 268. The teacher's negative feedback in the L1 is immediately followed by Taro's strong nod in line 269 .

As shown above, the students' verbal or nonverbal negative responsiveness often triggered the teacher's CS. 


\section{Effects of Codeswitching}

In this section the effects of teacher CS into the L1 triggered by the students' negative responsiveness will be examined. Interestingly, as can be seen in the examples in the previous section, when the teacher switched to the L1 in reaction to the students' negative responsiveness, the switches promptly produced reactions to the teacher's preceding utterances. In other words CS seemed to result in the resumption of the flow of interaction. These findings are shown in the left half of Figure 1. When the teacher chose to take Path A (CS to L1) after students displayed negative responsiveness, the flow of interaction resumed.

Figure 1: The relationship between students' negative responsiveness and CS

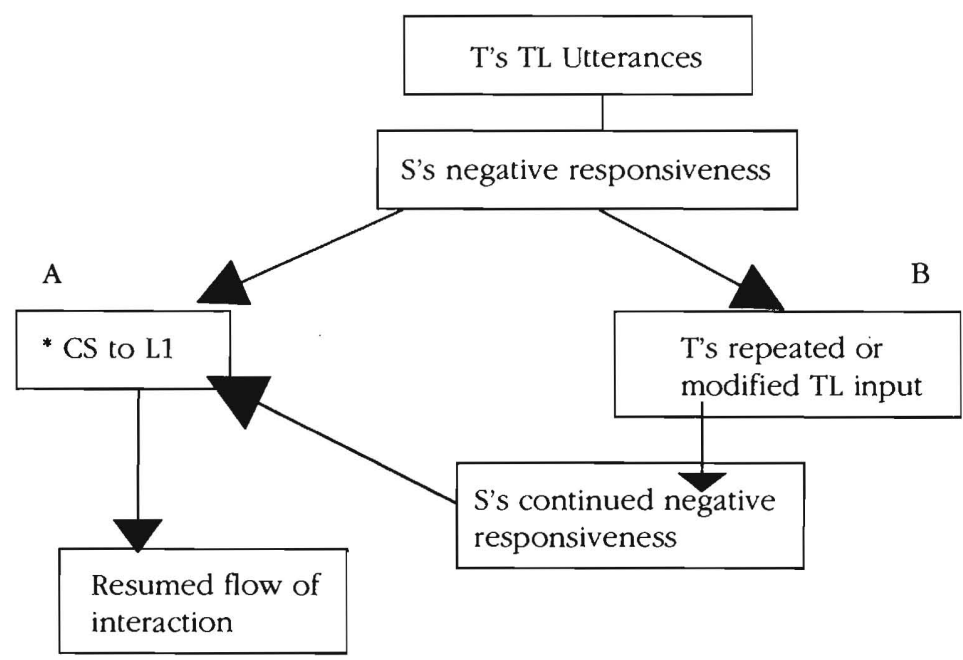

* By the teacher or one of the students.

T: $\quad$ Teacher

CS: Codeswitching

S: $\quad$ Student

TL: $\quad$ Target language (English)

L1: $\quad$ Students' first language (Japanese)

However the teacher did not always switch to Japanese after the students exhibited negative responsiveness. She occasionally repeated or modified her TL utterances. In such cases the students' negative 
responsiveness continued, and only when the teacher or one of the students switched into Japanese did the flow of the interaction resume. Consider Examples 12 and 13.

Example 12

((The teacher and Taro are talking about Taro's girlfriend.))

$\mathrm{t}: \mathrm{n} \mathrm{n} \mathrm{n}$

80. Teacher: Hum. (1.0) oh kay so how did you get a girlfriend?

$$
t: n
$$

81. Taro: Girlfriend

82. Teacher: hun how

$\mathrm{t}: \mathrm{n}$

83. Taro: $\quad$ how $=$

t:n t:n

84. Teacher: $=<$ did you get a girlfriend $>$

85. Taro: itsu getto shitaka tte? (.) [ah:::]

'When did I get a girlfriend? Uhmm.'

86. Teacher: [how]

87. Taro: $\quad$ how $k a{ }^{\circ}$ how $t t e^{\circ}$ ((looks at Shin))

'Oh how, how'

88. Shin: $\quad$ how how how

89. Taro: $\quad{ }^{\circ}$ how tte nani ${ }^{\circ}$

'What does how mean?'

90. Shin: $\quad$ how ttenee how dayo douyatte

'How means how. douyatte (in Japanese)'

91. Taro: oh (.) ano::u sono:: nomi drinking de

'Well, uhm, \{we met when we went\} drinking.'

In lines 82 and 84 , the teacher repeats her question at a slower speed. However, Taro fails to respond to the teacher's question correctly (line 85), and the teacher utters "how" again in line 86. Taro then looks at Shin (line 87) and asks him for the meaning of "how" in line 89. In line 90, Shin tells Taro the meaning in Japanese and finally Taro is able to answer the teacher's question. In the next example, the teacher switches into Japanese after she has repeated the TL utterances a few times.

\section{Example 13}

((The teacher tells Taro to read one of his slips and he begins to read.))

130. Taro: ((reading)) I'm starting to look for a job. (2.0) what kind

(1.0) ((Taro grins and tilts his head)) 
131. Teacher: that's ((points to Taro's slip))

132. Taro: ((clearing his throat))

$$
\text { t:n t:n }
$$

133. Teacher: what is the (.) that's A. (.) un sorega A?

'Is that $\mathrm{A}$ ?'

134. Taro: $\quad$ uun B

'No, B.'

After reading one of his slips, Taro grins and tilts his head. In line 131 the teacher points to the slip of paper Taro just read and asks which slip of paper it is. However, Taro fails to respond and just clears his throat (line 132). The teacher then repeats the question in the TL twice (line 133). However, Taro still fails to respond and just gives short nods. Finally, the teacher switches into Japanese. This CS is followed by Taro's response in line 134. These examples show that, as indicated in Figure 1, when the teacher took Path B (repetition or modification of the TL input), the students' negative responsiveness continued, and the flow of interaction did not resume until the teacher or one of the students switched into the L1.

To be sure, some readers might wonder whether the L1 use by the students triggers the teacher's CS; however, an analysis of the entire transcript shows that while $50.3 \%$ of the students' talk was in the L1, the teacher used the L1 in only $18.47 \%$ of her talk. Moreover, only $30.77 \%$ ( 12 times) of the students' talk directed to the teacher in the L1 (a total of 37 times) resulted in the teacher's use of L1. These findings suggest that the teacher did not regularly switch to the L1 after the students used the L1.

In summary, when the students showed negative responsiveness caused by their lack of comprehension, the teacher either switched into Japanese or used repetition or modification of the TL input. When the teacher switched into Japanese, the students reacted in a timely manner, and the flow of interaction could be resumed. On the other hand, when the teacher repeated or modified her previous TL utterances, the students' negative responsiveness continued. When this happened, the teacher or one of the students then used the L1, which resulted in the resumption of the flow of interaction.

\section{Conclusion}

This paper investigated three research questions regarding teacher CS in an EFL classroom in Japan: 1) What functions does L1 use or CS serve in teacher talk; 2) In what discourse context does CS occur; and 3) What is the effect of CS? 
It was shown that the teacher in the present study used CS when explaining prior TL utterances, giving instructions, defining unknown words, and providing positive and negative feedback. The study also indicates that regardless of the nature of the specific discourse function performed, teacher CS into the L1 was always in response to the students' behavior, either their positive achievement (two instances) or their negative responsiveness ( 28 instances). The main interactional consequence was that when the teacher switched into Japanese in response to students' negative responsiveness, the flow of interaction was restored. Thus the teacher's use of CS into the L1 affected the interaction by either fortifying it (after a positive achievement) or restoring it (after negative responsiveness).

The chief pedagogical implication of this result is that in EFL classes with students whose proficiency in the TL and motivation are low, CS into the L1 may allow the teacher to enhance the flow of interaction in the TL.

\section{Acknowledgments}

The author would like to thank. Dr. Noël Houck and the anonymous JALT reviewers for their valuable suggestions and encouragement.

Yuri Hosoda teaches English at Temple University Japan and Dokkyo University.

\section{Notes}

1. According to Fotos (1995), when CS research first began in the 1950s CS was regarded as undesirable behavior on the part of people who could not speak fluently in the L2. For example, Weinreich (1953) claims that one's transition from one language to the other within a single sentence or on a given occasion is not the behavior of an ideal bilingual. Labov (1971, as cited in Gumperz, 1982) calls CS "idiosyntactic behavior" (p. 70). In fact, Dabène and Billiez (1986) note that some educators still view multilingual competence in immigrant children negatively-probably because they believe that multilingual competence impedes the success of target language acquisition.

2. However, current research also shows that some CS, especially CS among low-proficiency L2 speakers, is indeed a strategy to compensate for communication problems (see Færch \& Kasper, 1983; Poulisse, 1997; Wagner \& Firth, 1997).

3. Myers-Scotton's (1993a) Matrix Language-Frame model provides an explanation for the frequent CS of nouns. For a detailed discussion on this point, see Myers-Scotton (1993a, pp. 493).

4. In her Markedness Model, Myers-Scotton (1993c) suggests two alternative types of CS: "unmarked" and "marked." For further discussion, see MyersScotton (1993c).

5. According to Merritt et al. (1992), although there are more than 30 mother tongues in Kenya, most of these languages have little, if anything, in writ- 
ten form.

6. The STEP third level is usually considered to be equivalent to a TOEFL score of around 400 .

7. The "strip story" activity was originally introduced by Gibbon (as cited in Nation, 1995). In the present study, the teacher cut up the dialogue the students had studied in the previous lesson into four pieces so that each student could have two pieces. The dialogue is one between a man and a woman, and each piece contains one turn by the man and one turn by the woman. The students had to put their pieces together to form the complete dialogue.

8. The teacher also used English utterances for feedback, such as "O.K.," "mhm," "yes," "yeah," and "right," throughout the lesson. These and the CS backchanneling utterances were categorized according to Sinclair and Coulthard's (1975), various classes of feedback acts: evaluate, marker, acknowledge, reply, or accept acts. It was found that the teacher used evaluate acts, which are characterized by a high falling tone that shows strong agreement, only for two CS responses. Other instances were categorized as marker, acknowledge, reply or accept acts. In this paper, only the two evaluate acts, both of which are positive, are regarded as "positive feedback."

9. Although Bilmes (1997) is talking about conversation, a different speech event from classroom interaction, interaction in a class between a teacher and only two students can be much like conversation.

10. In their analysis of interviews between counselors and students at a junior college Erickson and Shultz (1982) have shown that knowing when to do or say something (in a timely manner) is as fundamental as knowing what to do or say in face-to-face interaction. According to these authors, regularity in timing, expressed at the level of speech prosody and kinesic prosody, is essential to the success of interaction.

\section{References}

Adendorff, R. (1996). Functions of code switching among high school teachers and students in Kwazulu and implications for teacher education. In K. M. Bailey and D. Nunan (Eds.), Voices from the language classroom (pp. 388406). Cambridge: Cambridge University Press.

Atkinson, D. (1987). The mother tongue in the classroom: A neglected resource? English Language Teaching Journal, 41, 241-247.

Atkinson, J. M., \& Heritage, J. (1984). Structure of social action: Studies in conversation analysis. New York: Cambridge University Press.

Auer, J. C. P. (1984). Bilingual conversation. Amsterdam: Benjamins.

Auerbach, E. R. (1993). Reexamining English only in the ESL classroom. TESOL Quarterly, 27, 9-32.

Bilmes, J. (1997). Being interrupted. Language in Society, 26, 507-531.

Blom, J., \& Gumperz, J. J. (1972). Social meaning in linguistic structure: Codeswitching in Norway. In J. J. Gumperz \& D. Hymes (Eds.), Directions in sociolinguistics: The ethnograpby of communication (pp. 407-434). New York: Holt, Rinehart and Winston.

Brown, J. D. (in press). Language survey research. Cambridge: Cambridge Uni- 
versity Press.

Canagarajah, A. S. (1995). Functions of codeswitching in ESL classrooms: Socializing bilingualism in Jaffna. Journal of Multilingual and Multicultural Development, 6 (3), 173-195.

Dabène, L. (1990). Le parler bilingue issus de l'immigration en France. In R. Jacobson (Ed.), Codeswitching as a worldwide phenomenon (pp. 159-168). New York: Peter Lang.

Dabène, L., \& Billiez, J. (1986). Codeswitching in the speech of adolescents born of immigrant parents. Studies in Second Language Acquisition, 8, 309325.

Davis, K. A. (1992). Validity and reliability in qualitative research on second language acquisition and teaching. TESOL Quarterly, 26. 605-608.

Davis, K. A. (1995). Qualitative theory and methods in applied linguistic research. TESOL Quarterly, 29(3), 427-453.

Duppenthaler, P., \& Yoshizawa, K. (1997). A study of code switching in casual conversation between a native speaker of English and a native speaker of Japanese. Temple University Japan Working Papers in Applied Linguistics, 10, 133-149.

Eastman, M. C. (1992). Codeswitching as an urban language-contact phenomenon. Journal of Multilingual and Multicultural Development, 13, 1-17.

Erickson, F., \& Shultz, J. (1982). The counselor as gatekeeper: Social interaction in interviews. New York: Academic Press.

Faerch, C., \& Kasper, G. (1983). Plans and strategies in foreign language communication, In C. Faerch \& G. Kasper (Eds.), Strategies in interlanguage communication (pp. 20-60). London: Longman.

Fotos, S. (1995). Japanese-English conversational codeswitching in balanced and limited proficiency bilinguals. Japan Journal of Multilingualism and Multiculturalism, 1, 1-15.

Fujita, M. (1997). Uncomfortable moments in team-teaching. Temple University Japan Working Papers in Applied Linguistics, 10, 86-96.

Gardner-Chloros, P. (1991). Language selection and switching in Strasbourg. Oxford: Clarendon Press.

Goyvaerts, D. L. (1992). Codeswitching in Bukavu. Journal of Multilingual and Multicultural Development, 13 (1 \& 2), 71-81.

Grosjean, F. (1982). Life with two languages: An introduction to bilingualism. Cambridge, MA: Harvard University Press.

Gumperz, J. J. (1982). Discourse strategies. Cambridge: Cambridge University Press.

Hutchby, I., \& Wooffitt, R. (1998). Conversation analysis. Malden, MA: Blackwell. Itani, R. (1996). Semantics and pragmatics of bedges in English and Japanese. Tokyo: Hitsuji Shobo.

Kaneko, T. (1991). The role of the first language in foreign language classroom. Unpublished dissertation, Temple University Japan, Tokyo.

Kato, M. A. (1994). Metalinguistic reflections on code-switching. In L. Barbara \& M. Scott (Eds.), Reflections on language learning (pp. 122-137). Clevedon: Multilingual Matters. 
LoCastro, V. (1996). English language education in Japan. In H. Coleman (Ed.), Society and the language classroom (pp. 40-58). Cambridge: Cambridge University Press.

Maynard, S. (1993). Discourse modality: Sensitivity, emotion and voice in the Japanese language. Amsterdam: Benjamins.

Merritt, M., Cleghorn, A., Abagi, J. O., \& Bunyi, G. (1992). Socializing multilingualism: Determinants of codeswitching in Kenyan primary classrooms. Journal of Multilingual and Multicultural Development, 13 (1 \& 2), 103-121.

Mitsuo, S. (1997). Situations where minimal vocalizations without nods and nods without minimal vocalizations occur in Japanese interaction. Temple University Japan Working Papers in Applied Linguistics, 10, 27-38.

Myers-Scotton, C. (1993a). Common and uncommon ground: Social and structural factors in codeswitching. Language in Society, 22, 475-503.

Myers-Scotton, C. (1993b). Duelling languages: Grammatical structure in codeswitching. Oxford: Claredon.

Myers-Scotton, C. (1993c). Social motivations for codeswitching: Evidence from Africa. Oxford: Claredon.

Nation, I. S. P. (1995). Language teaching techniques. Tokyo: Temple University Japan.

Nishimura, M. (1989). Topic comment construction in Japanese-English codeswitching. World Englishes, 8, 365-377.

Nishimura, M. (1995). Functional analysis of Japanese/English codeswitching. Journal of Pragmatics, 23, 157-181.

Ogane, E. (1997). Codeswitching in EFL learner discourse. JALT Journal, 19 (1), 106-122.

Polio, C., \& Duff, P. (1994). Teachers' language use in university foreign language classroom: A qualitative analysis of English and target language alternation. Modern Language Journal, 78, 313-326.

Poplack, S. (1980). Sometimes I'll start a sentence in English y termino en espanol: Toward a typology of code-switching. Linguistics, 18, 581-618.

Poplack, S. (1988). Contrasting patterns of codeswitching in two communities. In M. Heller (Ed.), Codeswitching: Anthropological and sociolinguistic perspectives (pp. 215-244). Berlin: Mouton de Gruyter.

Poulisse, N. (1997). Compensatory strategies and the principles of clarity and economy. In G. Kasper \& E. Kellerman (Eds.), Communication strategies (pp. 49-64). London: Longman.

Sacks, H., Schegloff, E., \& Jefferson, G. (1974). A simplest systematics for the organization of turn-taking for conversation. Language, 50, 696-735.

Sinclair, J. M., \& Coulthard, R. M. (1975). Towards an analysis of discourse. London: Oxford University Press.

Tannen, D. (1984). Conversational style. New Jersey: Ablex Publishing.

Wagner, J., \& Firth, A. (1997). Communication strategies at work. In G. Kasper \& E. Kellerman (Eds.), Communication strategies, (pp. 323-344). London: Longman.

Weinreich, U. (1953). Languages in contact. The Hague: Mouton. 


\section{Appendix \\ Transcription Conventions}

[ ] overlapping talk

$=\quad$ latched utterances

(0.0) timed pause (in seconds)

(.) a short pause

co:lon extension of the sound or syllable

co::lon a more prolonged stretch

falling intonation (final)

continuing intonation (non-final)

rising intonation (final)

CAPITAL emphasis

$\circ \circ$

passage of talk that is quieter than surrounding talk

$<>$

$><$ passage of talk that is slower than surrounding talk

hh passage of talk that is faster than surrounding talk.

*hh audible aspirations

(hh) audible inhalations

(( )) laughter within a word comment by the transcriber problematic hearing that the transcriber is not certain about idiomatic translation of Japanese utterances words or phrases which are not explicitly stated in the Japanese versions. 